\title{
最近のスルホン化について
}

\author{
洗羭工業を中心に \\ 森昭・永山升三 \\ ライオン油脂株式会社研究部 (東京都江戸川区平井 3 丁目)
}

\section{The Status of Sulfonation Reaction in Detergent Industry}

Akira Mori and Masuzo Nagayama

Lion Fat and Oil Co., Ltd., Research Department

(3-chome, Hirai, Edogawa-ku, Tokyo)

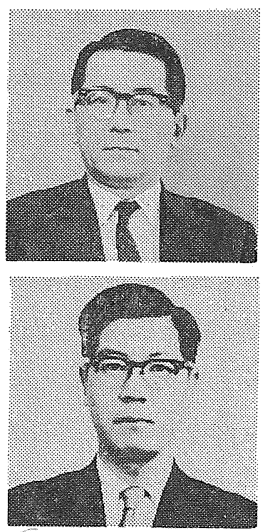

\section{1 緒}

言

スルホン化反応は染料を中心とする有機化学工業にお いて古くからなじみ深いユニットプロセスであるが，合 成洗㓮の歴史に掠いても，1916 年の I.G. 社の Nekal (アルキルナフタリンスルホン酸 Na）や 1930 年発表 の Böhme 社の Gardinol（高級アルコール硫酸エステ ル $\mathrm{Na}$ ）に始まって，今日に至るまで陰イオン界面活性 剤の分野においてきわめて重要な役目をしている。

陰イオン界面活性剂を主軸とする合成洗剤工業が急速 な成長を遂げ今日の巨大な化学産業部門を形成するに至 ったのはこの四分の一世紀のことで，とくにアルキルベ ンゼンスルホン酸がその主流となり石油化学工業の発展 とともに伸長することができた。

わが国に括いても順調な生産上昇率を示し昭和 44 年 度は家庭用粒状洗剂で 42 万 $\mathrm{t}$, 同液体洗剂で 15 万 $\mathrm{t}$, 工業用も合計すると約 65 万 $\mathrm{t}$ に達し, 自由世界におい て第 2 位となっている。

しかしながら 1 人当たりの消費量は 1966 年の統計で $5.9 \mathrm{~kg} /$ 人・年 で世界 32 位 $^{1)}, 1967$ 年で $6.6 \mathrm{~kg} /$ 人・年 で 17 位 $^{2)}$ となって打り，欧州の約 $1 / 2$, 米国の約 $1 / 3$ に すぎない。最近 GNP 比較による経済生長の論義が盛ん であるが，それに比較して洗浄文化水準は低すぎるとい わねばなるまい。

しかしわが国の洗剤の性能，価格 ${ }^{2}$ ，製造技術はすで に世界一流の水準に達していると考えられる。

スルホン化反応は染料，医薬品の製造のほか，石油精 製の硫酸洗浄，フェノール製造の中間体製造としてなど 多方面に活用されてきたが，そのユニットは小規模であ るか，またはフェノールの合成法においてはすでに過去 のものになりつつあり, 1950 年以降 スルホン化反応の 主流は界面活性剤の製造に移り, 今後もこの傾向は変わ ることはあるまい。
スルホン化反応に関する従来の文献としては，Gilbert $^{3)}$, Cerfontain $^{4)}$ の成書のほか 赤林氏の総説 ${ }^{5}$ があ る。また，須々木らは本誌に先にその製造装置について まとめている゙。

ここでは, それらとの重複のないようにその後に発表 された文献を中心に洗剂工業に関倸ある事項を中心にま とめた。

スルホン基を導入する手段としてはいろいるあるが， ここでは界面活性剂工業で用いられる手段, 原料基づ いて述べる必要がある。すなわちその疎水基原料も天然 油脂原料のヒマシ油に始まって高級アルコールの製造に 至り,さらに石油化学の進展によりアルキルベンゼンや 枋レフィン, $n$-パラフィンに至るまで使用されるよう になった。疎水基源の変還は化学構造の面からもいわゆ る生分解性洗剂への転換問題も含めて, より界面化学的 に合理的な構造（たとえばアルキルベンゼンのフェニル 基は不要で長鎖構造に置換する) 一の追及改善にも関連 している。

したがってスルホン化を広義に解勫して sulfonation, sulfation, halosulfonation, sulfoxidation, sulfitation $に$ ついて述べる。

最近とくに無水硫酸を使用する方法が広く利用され始 め，その結果多くの工業的に有利な点が見いだされつつ ある。スルホン化剂のコスト比較は表-1 に示した通り であり ${ }^{7)}$ とくに安定化無水硫酸使用の利点が見られる が，さらにイオウの燃焼ガスの接触酸化による無水硫酸 を直接スルホン化プロセスに使用する一連のプロセスが 普及しつつある。とくにオレフィンのスルホン化反応の 確立に主要な基盤となった。

\section{2 芳香族のスルホン化反応}

芳香族のスルホン化反応に関する理論的考察はかなり 古くからあるが，最近でもな捛研究が続けられている。 
表-1 スルホン化剤の経済比較

\begin{tabular}{|c|c|c|c|}
\hline \multicolumn{4}{|c|}{ A. アルキルベゼン $100 \mathrm{~kg}$ 当たりのスルホン化肪価格 } \\
\hline スルホン化斉 & 数量 $(\mathrm{kg})$ & 単価 (円 $/ \mathrm{kg})$ & 価格（円） \\
\hline & 150 & 20.9 & 3,135 \\
\hline 発 煙 硫 酸 & 115 & 21.9 & 2,519 \\
\hline 無水硫酸(安定化) & 35.6 & 40.4 & 1,438 \\
\hline
\end{tabular}

B. 高級アルコール $100 \mathrm{~kg}$ 当たりの硫酸化㓯価格

\begin{tabular}{c|c|c|c}
\hline 硫酸 化剂 & 数量 $(\mathrm{kg})$ & 単価 (円 $/ \mathrm{kg})$ & 価格 (円) \\
\hline クロルスルホン酸 & 58 & 58.4 & 3,387 \\
無水硫酸(安定化) & 40 & 40.4 & 1,616 \\
\hline
\end{tabular}

濃硫酸による芳香族化合物のスルホン化の攻撃試剂とし ては, $\mathrm{H}_{3} \mathrm{SO}_{4}^{+}, \mathrm{SO}_{3}, \mathrm{HSO}_{3}^{+}, \mathrm{S}_{2} \mathrm{O}_{6}$ および $\mathrm{H}_{2} \mathrm{~S}_{2} \mathrm{O}_{7}$ が 考えられ，これらは以下の平衡によって生成してくる。

$$
\begin{aligned}
& 2 \mathrm{H}_{2} \mathrm{SO}_{4} \rightleftharpoons \mathrm{H}_{3}^{+} \mathrm{SO}_{4}+\mathrm{HSO}_{4}^{-} \\
& 2 \mathrm{H}_{2} \mathrm{SO}_{4} \rightleftharpoons \mathrm{SO}_{3}+\mathrm{H}_{3} \mathrm{O}^{+}+\mathrm{HSO}_{4}^{-} \\
& 3 \mathrm{H}_{2} \mathrm{SO}_{4} \rightleftharpoons \mathrm{HSO}_{3}^{+}+\mathrm{H}_{3} \mathrm{O}^{+}+2 \mathrm{HSO}_{4}^{-} \\
& 4 \mathrm{H}_{2} \mathrm{SO}_{4} \rightleftharpoons \mathrm{S}_{2} \mathrm{O}_{6}+2 \mathrm{H}_{3} \mathrm{O}^{+}+2 \mathrm{HSO}_{4}^{-} \\
& \mathrm{H}_{2} \mathrm{SO}_{4}+\mathrm{SO}_{3} \rightleftharpoons \mathrm{H}_{2} \mathrm{SO}_{4} \cdot \mathrm{SO}_{3} \text { または } \mathrm{H}_{2} \mathrm{~S}_{2} \mathrm{O}_{7}
\end{aligned}
$$

Cerfontain は芳香族化合物の スルホン化の反忘速度 とその異性体比の, 硫酸の濃度による変化を二つのメカ ニズムにより説明している8)。

メカニズム $[I]$

$$
\begin{aligned}
& \mathrm{ArH}+\mathrm{H}_{2} \mathrm{~S}_{2} \mathrm{O}_{7} \rightleftharpoons \stackrel{\oplus}{\mathrm{Ar}}\left\langle\mathrm{SO}_{3} \ominus+\mathrm{H}_{2} \mathrm{SO}_{4}\right. \\
& \stackrel{\oplus}{\mathrm{Ar}}<\mathrm{SO}_{3} \ominus+\mathrm{HSO}_{4}^{-} \rightarrow \mathrm{ArSO}_{3} \ominus+\mathrm{H}_{2} \mathrm{SO}_{4} \\
& \text { メカニズム [II] }
\end{aligned}
$$

$$
\mathrm{ArH}+\mathrm{H}_{2} \mathrm{SO}_{4} \oplus \rightleftharpoons \stackrel{\oplus}{\mathrm{Ar}}\left\langle\underset{\mathrm{SO}_{3} \Theta}{\mathrm{H}}+\mathrm{H}_{3} \mathrm{O} \oplus\right.
$$$$
\stackrel{\oplus}{\mathrm{Ar}}\left\langle\underset{\mathrm{SO}_{3} \ominus}{\mathrm{H}}+\mathrm{HSO}_{4} \ominus \rightarrow \mathrm{ArSO}_{3} \ominus+\mathrm{H}_{2} \mathrm{SO}_{4}\right.
$$

メカニズム[I] ではスルホン化の反応速度は $\mathrm{H}_{2} \mathrm{~S}_{2} \mathrm{O}_{7}$ の活量に比例する。硫酸の濃度が低い場合にはスルホン 化の速度の対数は $\mathrm{H}_{3} \mathrm{SO}_{4} \oplus$ の活量の対数に比例する。そ こで新しいメカニズムとして $[$ III] の寄与を考えている。

発煙硫酸および無水硫酸によるスルホン化では副生成 物としてスルホンが生成することが知られている。

Cerfontain らはニトロメタンおよびトリクロルフル オロメタン中でのクロルベンゼンの無水硫酸によるスル ホン化の研究よりつぎの結果を得ている ${ }^{9)} 。$

(1) スルホン化の反応速度は次式に従う。

$\mathrm{CH}_{3} \mathrm{NO}_{2}$ 中 $d\left[\mathrm{ArSO}_{3} \mathrm{H}\right] / d t=k[\mathrm{ArH}]\left[\mathrm{SO}_{3}\right]^{2}$

$\mathrm{CFCl}_{3}$ 中 $d\left[\mathrm{ArSO}_{3} \mathrm{H}\right] / d t=k[\mathrm{ArH}]\left[\mathrm{SO}_{3}\right]$

(2) スルホンの生成は非常に少ない $(<1 \%)$ 。

(3) スルホン酸無水物を生成する。

無水硫酸によるスルホン化，スルホン化のメカニズム としては次式のように考えている。

$$
\mathrm{CFCl}_{3} \text { 中 } \mathrm{ArH}+\mathrm{SO}_{3} \stackrel{\text { 漣い }}{\longrightarrow} \stackrel{\oplus}{\mathrm{Ar}} \mathrm{H}_{\mathrm{SO}_{3} \ominus}^{\mathrm{H}} \stackrel{\text { 速い }}{\longrightarrow} \text { 生成物 }
$$

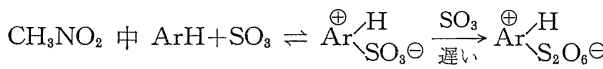

$$
\begin{aligned}
& \stackrel{\text { 速以 }}{\longrightarrow} \mathrm{ArS}_{2} \mathrm{O}_{6} \mathrm{H} \\
& 2 \mathrm{ArS}_{2} \mathrm{O}_{6} \mathrm{H} \rightarrow\left(\mathrm{ArSO}_{2}\right)_{2} \mathrm{O} \cdot \mathrm{H}_{2} \mathrm{~S}_{2} \mathrm{O}_{7} \\
& \mathrm{Ar} \oplus\left\langle<\mathrm{SO}_{3} \Theta+\mathrm{ArS}_{2} \mathrm{O}_{6} \mathrm{H} \rightarrow(\mathrm{ArSO})_{2} \mathrm{O} \cdot \mathrm{H}_{2} \mathrm{SO}_{4}\right. \\
& \stackrel{\mathrm{SO}_{3}}{\longrightarrow}\left(\mathrm{ArSO}_{2}\right)_{2} \mathrm{O} \cdot \mathrm{H}_{2} \mathrm{~S}_{2} \mathrm{O}_{7}
\end{aligned}
$$

$\mathrm{ArS}_{2} \mathrm{O}_{6} \mathrm{H}+\mathrm{SO}_{3} \rightleftharpoons \mathrm{ArS}_{3} \mathrm{O}_{9} \mathrm{H}$

$\mathrm{ArS}_{3} \mathrm{O}_{9} \mathrm{H}+\mathrm{ArH} \rightarrow \mathrm{ArSO}_{2} \mathrm{Ar}+\mathrm{H}_{2} \mathrm{~S}_{2} \mathrm{O}_{7}$

スルホンの生成は硫酸をスルホン化㓮として使用する 場合ほとんど無視できる。無水硫酸による反応でも置換 アルキル基の増大により減少し, 洗剤用のアルキレート の場合でもかなり少ない" ${ }^{10)} 。$

スルホン酸無水物の生成は洗剤用アルキレートにおい て無水硫酸によるスルホン化を行なら場合かなり生成す ることが Gilbert によって認められている ${ }^{11)} 。$

この結果で海水硫酸の“過剩率の大きいほど”, “反 応時間の短いほぼ”酸無水物の生成が多く，実際連続無 水硫酸法によるスルホン化では後処理によりこのものを 分解してスルホン酸に変えてやる必要がある。

酸無水物は中性水溶液では徐々に分解して $\mathrm{pH}$ を下 げるのでスルホン酸を中和の状態で水を添加し加水分解 する。

副反応として酸化反応を起こすとキノイド型化合物を 生成して着色の原因になる。脱アルキル化反応は洗剂用 アルキレートのスルホン化副反応としてはほとんど無視 できるようである。

モノアルキルベンゼンのスルホン化は一般に $o, p$ の 二つの位置異性体を生ずる。

\begin{tabular}{|c|c|c|c|c|c|c|}
\hline \multirow{2}{*}{ サンプリング } & \multicolumn{3}{|c|}{$4 \sim 8^{\circ} \mathrm{C}$ スルホン化 } & \multicolumn{3}{|c|}{$50^{\circ} \mathrm{C}$ スルホン化 } \\
\hline & $\begin{array}{c}\text { 転換率 } \\
(\%)\end{array}$ & $o$ & $p$ & $\begin{array}{c}\text { 転換率 } \\
(\%)\end{array}$ & $o$ & $p$ \\
\hline $\begin{array}{l}\text { スルホン化開 } \\
\text { 始 } 20 \mathrm{~min} \text { 後 }\end{array}$ & 21.7 & 83 & 67 & 64.3 & 26 & 74 \\
\hline 同 $40 \mathrm{~min}$ 後 & 69.6 & 31 & 69 & 99.91 & 25 & 75 \\
\hline 熟 成 後 & 99.95 & 27 & 73 & - & - & - \\
\hline 廃酸分離後 & 99.98 & 25 & 75 & 99.73 & 21 & 79 \\
\hline
\end{tabular}

アルキル基が大きい場合立体障害のためにトルエンな どの短鎖のものに比較して洗剂用アルキレートでは $o-$ 体の生成比率はかなり小さいことが期待される。

実際 Gray らによれば $o, p$ の比は 1-フェニルアルカ

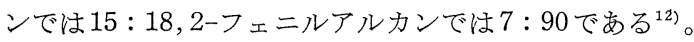

スルホン化反応は一種の可逆反応で, その脱スルホン 化しやすさは $o>p^{-\gg m}$ の順であるから ${ }^{13)}$, スルホン 化の温度上昇, 時間の経過により 0 - 体の割合は低下す る $(\text { 表 }-2)^{14)}$ 。

発煙硫酸によるスルホン化では鎖長およびベンゼン核 ・の位置により各異性体の相詨スルホン化速度が異なるた

表-2 ヘキシルベンゼンのスルホン化に括けるオルト， パラ生成比 (20\% 発煙硫酸 $3.2 \mathrm{~mol})$ 


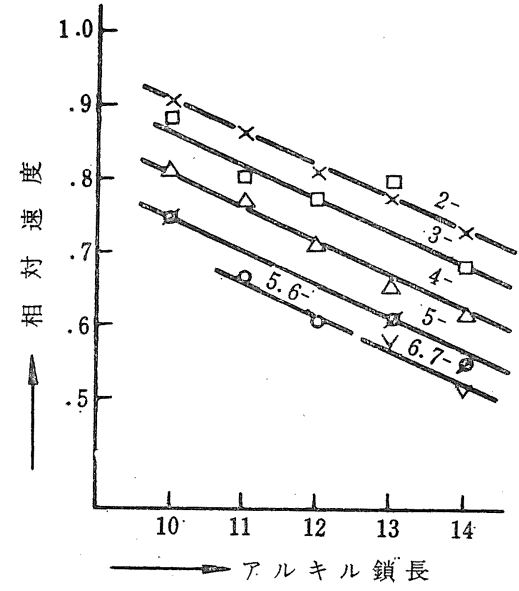

図-1 20\% 発煙硫酸によるアルキルベンゼン異性体の 相対スルホン化速度 (1-phenyldodecane のス ルホン化速度 1.0 とする。図中の数字はアルキ ル鎖中のベンゼン核位置を表わす。)

め選択的スルホン化が生ずる(図-1 $)^{15)}$ 。

しかし熟成によりこれらの選択的スルホン化は消滅す $\Xi^{16)}$ 。

アルキルベンゼンのスルホン化の工業的生産における 三，三の問題について述べる。

発煙硫酸によるアルキルベンゼンのスルホン化は過剰 （約 3 倍 $\mathrm{mol}$ ）の酸を使用することにより高反応率でス ルホン化される。スルホン化後, 過剩の酸は水で希釈し 適当な濃度にしリサイクルすると硫酸が連続相, スルホ ン酸が分散相となり相互に急速に分離して上層は高純度 のスルホン酸を得ることができることが見いだされ，連 続装置に広く採用されている ${ }^{17)}$ 。

分岐鎖アルキル基のハード型アルキルベンゼンではこ のような分離が $78 \%$ 硫酸で起きるが, 直鎖アルキル基 のソフト型のアルキルベンゼンでは 71〜 72\% において 生ずるため後者は水の添加量を増す必要がある ${ }^{18)}$ 。

無水硫酸によるスルホン化は不活性ガスにより希釈さ れたガス状無水硫酸をアルキルベンゼン中に吹き込んで やることにより比較的容易に進行する。最近では後述す るようにこの方法を連続化したものが大型の工場で広く 使用されている。そして副生物や硫酸の混在も少ない高 品質のものが得られている。ただこの反応は発熱が 300 $\mathrm{Btu} / \mathrm{lb} /{ }^{\circ} \mathrm{F}$ と大きいので熱の除去に工夫が必要である ${ }^{18)} 。$

アルキルベンゼンスルホン酸の工業的な製品には特有 臭がある。Seifert はその臭気成分を検索しケトン類, ジオレフィン類であることを認め, その脱臭にはヒドロ キシルアミン塩酸塩, 次亜塩素酸ナトリウム, ナトリウ ムボロヒドリドによる処理が有効であるとしている。

\section{3 オレフィンのスルホン化反応}

๙ーオレフィンスルホネート (AOS) の合成と性能に関
しては富山により詳述されている20)のでここではそれと 重複しないよら述べる。

アルキルベンゼンのフェニル基は親水基の受容体とし て大変好つごうであるが，より簡単な化学構造で反応性 に富むオレフィンの二重結合が研究対象となるのは当然 であらら。しかしながらこの反応は複雑な副反応を伴ら ため最近まで工業化が成功しなかった。

オレフィンは硫酸により硫酸エステル化され, 無水硫 酸によりスルホン化される。

はーオレフィンを用いた場合でもアルキル基のI 効果 により末端炭素は $\ominus$ に分極されるので硫酸の攻撃は内 部の炭素に向かって生ずる。

$$
\begin{aligned}
& \mathrm{R}-\mathrm{CH}=\mathrm{CH}_{2}+\mathrm{H}^{+} \stackrel{\text { 低温 }}{\longrightarrow} \mathrm{R}-\underset{\oplus}{\mathrm{CH}}-\mathrm{CH}_{3}
\end{aligned}
$$

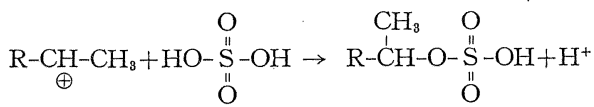

硫酸エステル化の反応は Livingston によって詳細に 研究された

๙ーオレフィンをペンタン，ヘキサン中で低温で反応す ると図-2 に示すような比率でモノ，ジェステルを生成 する。

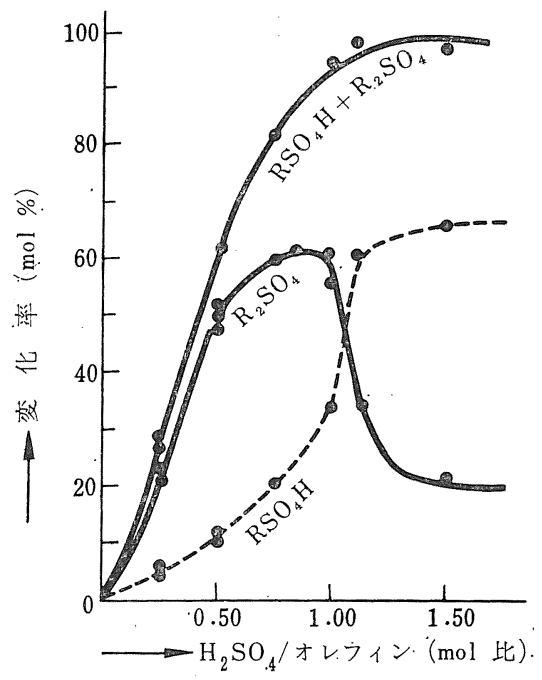

図-2 $0^{\circ} \mathrm{C}$ における $96 \% \mathrm{H}_{2} \mathrm{SO}_{4}$ によるドデセンの硫酸化

仿レフィンの 炭素数が 増加すると硫酸エステル化 しにくくなる。

ジェステルを加水分解すると第二アルコールが副生す る。 $0^{\circ} \mathrm{C}$ で $96 \%$ 硫酸を用い反応した場合は収率 $80 \%$ で， $90 \%$ に向上するには $-15^{\circ} \mathrm{C}, 98 \%$ 硫酸が必要であ る。

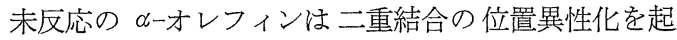
こす。反応温度が低い場合は $\Delta^{2}$ が大部合であるが，温 度が高くオレフィンが大過剩に加えられた場合, 未反応 の $\propto$ ーオレフィンは二重結合がさらに移動してランダム 
になる。

無水硫酸や無水硫酸・ルイス塩基錯体を用いて $\alpha$-才 レフィンをスルホン化するとアルキル基のＩ効果により 負に分極した末端炭素にスルホン化反応が行なわれる。 この研究はすでに 19 世紀に Lasarenko が発表してい るが23)，その後重要な発展峙なかった。また 1930 年代 の後半において du Pont 社の研究者が界面活性剂の製 造を目的としていくつかの先駆的な特許を得ている ${ }^{24)}$ 。 その後に至り無水硫酸のジオキサンやピリジン錯体を 用いる反応が多く研究され前者は C.M. Suter, F.G. Bodwell により，後者は A.P. Terentév により多くの 基礎的な研究成果が発表されている。

このような錯体を用いた場合生成した Z witterion は ルイス塩基により安定化されるものと考光られる。

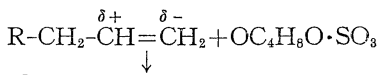

$$
\begin{aligned}
& {\left[\begin{array}{c}
\mathrm{R}-\mathrm{CH}_{2}-\stackrel{\oplus}{\mathrm{C}} \mathrm{H}-\mathrm{JH}_{2}-\mathrm{SO}_{2} \mathrm{O} \Theta \\
\mathrm{O}_{4} \mathrm{H}_{8} \mathrm{O}
\end{array}\right.} \\
& \left.\rightleftarrows \mathrm{R}-\mathrm{CH}_{2}-\stackrel{\oplus}{\mathrm{C}} \mathrm{H}-\mathrm{CH}_{2}-\mathrm{SO}_{2} \mathrm{O} \ominus+\mathrm{OC}_{4} \mathrm{H}_{8} \mathrm{O}\right]
\end{aligned}
$$

遊離の無水硫酸を用いて反応した場合は Zwitterion （I a) は不安定でつぎに示寸式に従ってアルケンスルホ ン酸（II a，II b) やサルトン (III, IV) を生成する。サ ルトンは加水分解によりアルケンスルホン酸とオキシア ルカンスルホン酸を生成する゙5)。

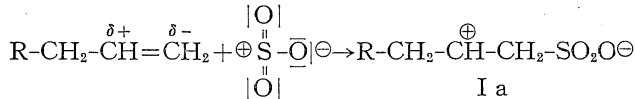

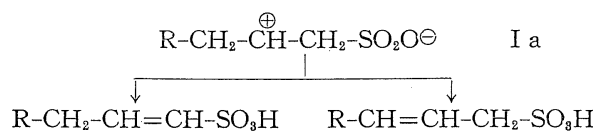

$$
\begin{aligned}
& \text { II a II b } \\
& \mathrm{R}-\mathrm{CH}_{2}-\stackrel{\oplus}{\mathrm{CH}}-\mathrm{CH}_{2}-\mathrm{CH}_{2}-\mathrm{SO}_{2} \mathrm{O} \ominus \rightarrow \mathrm{R}-\mathrm{CH}_{2}-\mathrm{CH}-\mathrm{CH}_{2}-\mathrm{CH}_{2} \\
& \text { I b }
\end{aligned}
$$

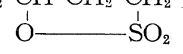

R- $\stackrel{\oplus}{\mathrm{C}} \mathrm{H}-\mathrm{CH}_{2}-\mathrm{CH}_{2}-\mathrm{CH}_{2}-\mathrm{SO}_{2} \mathrm{O} \ominus \rightarrow \mathrm{R}-\mathrm{CH}-\mathrm{CH}_{2}-\mathrm{CH}_{2}-\mathrm{CH}_{2}$

I c IV $\mathrm{OH}$
反応直後に生じた Z witterion I a のカルボニウムイ オンはヒドリドシフトにより I b I c 亿移行し, 得ら れるサルトンはIII(1.3 サルトン) $\mathrm{N}(1.4$ サルトン) に なっている。これはサルトン環の安定性と関係がある。 ひずみの大きい 4 員環の 1.2 サルトンは非常に不安定で あり，さらにまた Truce らは 3-オキシアルカンスルホ ン酸を脱水閉環すると 1.4 サルトンを生成することを見
いだしている22)。

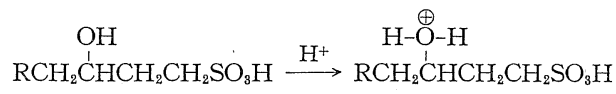

$$
\begin{aligned}
& \stackrel{-\mathrm{H}_{2} \mathrm{O}}{\longrightarrow} \mathrm{RCH}_{2} \stackrel{\oplus}{\stackrel{\oplus}{\mathrm{CHCH}}} \mathrm{H}_{2} \mathrm{CH}_{2} \mathrm{SO}_{8} \mathrm{H}
\end{aligned}
$$

$\mathrm{R} \stackrel{\mathrm{CHCH}}{\mathrm{CHCH}_{2} \mathrm{CH}_{2} \mathrm{SO}_{2} \mathrm{O}} \stackrel{-\mathrm{H}^{+}}{\longleftarrow} \stackrel{\oplus}{\mathrm{C}} \mathrm{HCH}_{2} \mathrm{CH}_{2} \mathrm{CH}_{2} \mathrm{SO}_{3} \mathrm{H}$

1,4 サルトンの 6 員環がシクロヘキセン類似のStaggered chain conforomation をとり，より安定であると 説明できる。

オレフィンのスルホン化において初期において生成す るはずの 1,2 サルトン (A) はきわめて不安定な化合物 と考えられる。

スチレンのようなヒドリドシフトができないオレフィ ンはサルトンダイマー（B）の生成が認められる ${ }^{26)}$ 。

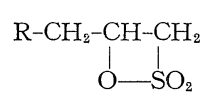

A

$$
\begin{aligned}
& \mathrm{R}-\mathrm{CH}-\mathrm{O}-\mathrm{SO}_{2} \\
& \mathrm{H}_{2} \stackrel{\mathrm{C}}{\mathrm{C}} \stackrel{\mathrm{C}}{\mathrm{C}} \mathrm{H}_{2} \\
& \mathrm{O}_{2} \mathrm{~S}-\mathrm{O}-\stackrel{\mathrm{C}}{\mathrm{C}} \mathrm{H}-\mathrm{R}
\end{aligned}
$$

$\mathrm{B}$
バッチ反応で遊離の無水硫酸によるスルホン化では著 しい反応率の低下と着色がある。

その原因はダイメリックサルトン (C) やカルビルサ ルフェート (D) の生成のほか内部二重結合オレフィン への異性化のためであろう27)。着色の原因はほかにオレ フィン中に含まれる不純成分が関係している ${ }^{28)}$ 。<smiles>[R]C1CC([R])O[Se]O1</smiles>

$\mathrm{C}$<smiles>[R]C1CCO[Se]O1</smiles>

$\mathrm{D}$
副反応生成物少なく高収率でスルホン化するためには 連続スルホン化装置の使用が必要でその詳細な条件につ

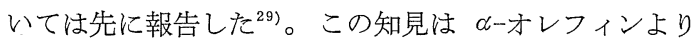
直接洗剂を工業的に得ることを可能にした。スルホン化 の機構, 初期反応生成物についての検討は現在われわれ の研究室で実施されているが，スルホン化後数秒の間は 1,2 サルトンまたは 1,2の Zwitterion の形が存在し, それが温度，時間の条件によってそれぞれ II ～IV に移 行して行く ${ }^{30)}$ 。

このスルホン化を工業化する場合問題となるのは，反 応熱が約 $50 \mathrm{kcal} / \mathrm{mol}^{31)}$ でアルキルベンゼンに比較して 30\% も大きく, 反応速度も約 100 倍程はやい ${ }^{322}$ ので反 応の制御は非常に困難なものがあり特別な連続反応装置 の開発が必要である ${ }^{20)}$ 。

サルトンの加水分解はアルキル切断が起きてオキシア ルカンスルホン酸とアルケンスルホン酸が生成し，その 機構は $\mathrm{B}_{\mathrm{AL}} 1-\mathrm{E} 1$ 型である ${ }^{33), 34) 。 ~}$

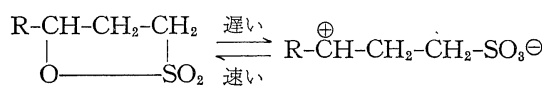




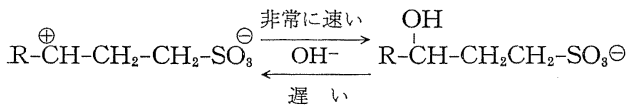

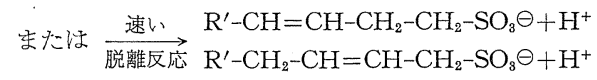

高温，酸性下で反応すると脱離反応が起きやすく $80 \%$ がアルケンスルホン酸となる。脱離は Saytzeff 則に従 うものの生成が多い。1，4 サルトンは 1，3 サルトンに 比較して加水分解速度がかなり遅い ${ }^{35)}$ 。

サルトンを塩やアルコラートの存在下に加熱してすべ てアルケンスルホン酸に変化させる試みがなされてい

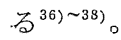

この場合 $\mathrm{E}-2$ 反応により脱離されるのであろう。

サルトン分解剤としてアミンなどの活性水素をもった 化合物を使用し，たとえば両性界面活性剤に誘導する試 タもなされている ${ }^{39}$ 。アミンの誘導体はキレート効果も ある ${ }^{40)}$ 。

今後オレフィンスルホン酸塩, およびその誘導体はい ろいろな分野で発展していくものと期待される。 フィンは Wax-Cracking 法のほか最近ではエチレン重 合法で三菱化成（株）により 国産化されようとしてい る $^{41)}$ 。

将来これらはアルキルベンゼンや，高級アルコール以 上にすぐれた洗剤原料として拡大を続けるであらう。

\section{4 アルコールの硫酸エステル化反応}

アルコールの硫酸エステル化反応は古くから知られて いるが脱水反応のため大過剩の硫酸を必要とするので, 最近では硫酸を使用することは比較的少なくなってい る。

このためクロルスルホン酸, 無水硫酸, スルファミン 酸が使用され，とくにクロルスルホン酸，無水硫酸の使 用は一般的である。

洗剂原料として見た場合 $-\mathrm{OH}$ 基の導入は，油脂から の製造はもちろん，石油化学の方法によってもコスト高

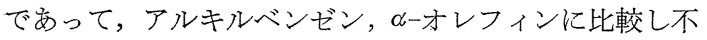
利である。

表-3 $\mathrm{C}_{12 \sim 14}$ アルコールの種々の試薬による硫酸化

\begin{tabular}{|c|c|c|c|c|c|}
\hline \multirow{2}{*}{ 試 } & \multirow{2}{*}{$\begin{array}{l}\text { 酸/ } \\
\text { アルコール } \\
\text { mol 比 }\end{array}$} & \multirow{2}{*}{$\begin{array}{c}\text { 反応温度 } \\
\left({ }^{\circ} \mathrm{C}\right)\end{array}$} & \multicolumn{2}{|c|}{$\begin{array}{c}\text { 品 } \\
\end{array}$} & 質 \\
\hline & & & $\begin{array}{l}\text { 界面活性 } \\
\text { 剂 }(\%)\end{array}$ & 油 分 & $\begin{array}{l}\text { 收率 } \\
(\%)^{\mathrm{b}}\end{array}$ \\
\hline $96 \% \mathrm{H}_{2} \mathrm{SO}_{4}$ & 2.3 & 55 & 14.2 & 3.4 & 80.6 \\
\hline $\begin{array}{c}96 \% \mathrm{H}_{2} \mathrm{SO}_{4} \\
\text { (四塩化炭素中) }\end{array}$ & 2 & 15 & 32.8 & 4.8 & 87.2 \\
\hline :20\% 発煙 硫 酸 & 3 & 35 & 9.4 & 2.0 & 82.4 \\
\hline $\begin{array}{l}20 \% \text { 発煙硫酸 } \\
\text { (エーテル中) }\end{array}$ & 1.2 & 15 & 14.7 & 10.8 & 57.7 \\
\hline スルフォミン酸 & 1.05 & 130 & 19.6 & 12.0 & 61.9 \\
\hline クロルスルホン酸 & 1.03 & 35 & 40.5 & 1.6 & 96.2 \\
\hline 無 水 硫 酸 & 1.02 & 35 & 44.0 & 3.0 & 93.6 \\
\hline
\end{tabular}

a. 全体当たり b. アルコールをベースとした值 表-4＼cjkstart硫酸エステルの酸性放置による劣化

\begin{tabular}{|c|c|c|c|}
\hline \multicolumn{4}{|c|}{ 高級アルコールの場合 } \\
\hline 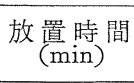 & 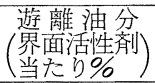 & 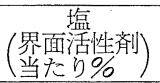 & 色 $\mathrm{RCD}^{\text {調 }}$ \\
\hline 0 & 4.31 & 2.77 & 0.30 \\
\hline 60 & 8.91 & 5.69 & 0.47 \\
\hline 180 & 7.65 & 6.21 & 0.41 \\
\hline \multicolumn{4}{|c|}{ 高級アルコールエトキシレートの場合 } \\
\hline $\begin{array}{c}\text { 放置時間 } \\
(\mathrm{min})\end{array}$ & $\begin{array}{l}\text { 遊離油分 } \\
\left(\begin{array}{l}\text { 界面活性剂 } \\
\text { 当たり\% }\end{array}\right)\end{array}$ & 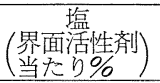 & ${ }^{\text {色 }} \mathrm{RCD}^{\text {調 }}$ \\
\hline 0 & 7.50 & 0.106 & 0.20 \\
\hline 15 & 7.72 & 0.075 & 0.20 \\
\hline 30 & 7.70 & 0.045 & 0.22 \\
\hline 60 & 8.20 & 0.062 & 0.23 \\
\hline 120 & 8.43 & 0.031 & 0.30 \\
\hline 180 & 8.53 & 0.156 & 0.46 \\
\hline
\end{tabular}

硫酸エステル化反応にいつてもそれらに比較し定量的 な反応到達率を得ることが困難でとくに長鎖のものはこ の傾向が大きい。各種硫酸化剤による $\mathrm{C}_{12 \sim 14}$ アルコー ルの硫酸エステル化結果を表-3 に示した ${ }^{3)}$ 。

硫酸エステルは酸性下に放置するとエステル結合の分 解が比較的急速に起き色相も劣化する ${ }^{42)}$ 。中和後もバッ ファーの添加により安定化する必要がある。

第二アルコールは第一アルコールに比較してさらに硫 酸エステル化しにくい。クロルスルホン酸を硫酸化剤と し溶剤を使用して低温で行なら必要があるが現在のとこ ろ実用化されていない。第二アルコールのエトキシレー トの硫酸エステル化も比較的低温で行なわれる ${ }^{43)}$ 。スル ファミン酸，クロルスルホン酸を用いた場合つぎの通り

(色調は Klett-Summerson 色差計 $5 \%$ 濃度での值)。

$$
\begin{array}{lcc}
\text { 硫 酸 化 剂 } & \text { 収率 mol\% } & \text { 色 調 } \\
\text { スルフ マミン酸 } & 95 \sim 97 & 75 \sim 120 \\
\text { クロルスルホン酸 } & 93 \sim 95 & 40 \sim 50
\end{array}
$$

実験室的な方法ではあるが硫酸を用いジメチルホルム アミドを溶剤として dicyclohexyl carbodiimide を使用 すると高収率でアルコール，フェノール，メルカプタ ン，アミン，オキシムなどを硫酸エステル化できる ${ }^{44)}$ 。 その反応機構はつぎのように考えられている。

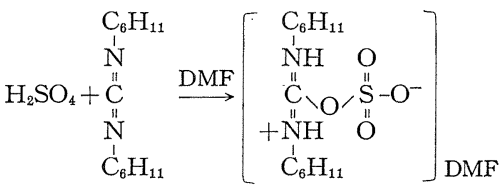

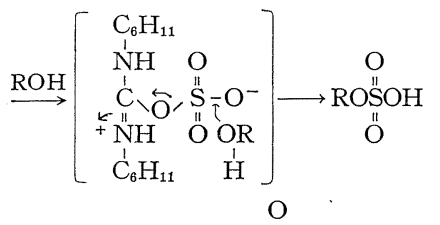

$+\mathrm{C}_{6} \mathrm{H}_{11} \mathrm{NHCNHC}_{6} \mathrm{H}_{11}$ 


\section{5 脂肪酸のスルホン化反応}

脂肪酸に無水硫酸を低温で反応すると $\alpha$ 位炭素にスル ホン化して 社では Amphoseife DN として工業化していたことが $\mathrm{PB}$ レポートに報じられている。

この分野に関する研究は Eastern Regional Research Laboratory の Stirton らや東京大学浅原教授の詳細な 報告が American Oil Chemists' Society や油化学に発 表されているのでここでは省略する ${ }^{44,45) 。 ~}$

๙ースルホン化の反応機構についてはいくつかの研究 があるが, 結果は一致してアシルサルフェートの生成を 中間体としている ${ }^{46)}$ 。

$$
\begin{aligned}
& \mathrm{RCH}_{2} \mathrm{COOH}+\mathrm{SO}_{3} \rightarrow \mathrm{RCH}_{2} \mathrm{COOSO}_{3} \mathrm{H} \\
& \rightarrow\left[\mathrm{RCH}^{2} \mathrm{COO}\right]^{-}+{ }^{+}\left[\mathrm{SO}_{3} \mathrm{H}\right]
\end{aligned}
$$

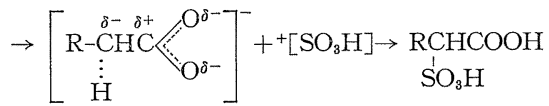

アシルサルフェートを加熱すると転位反応が起こり メースルホン酸となる。この転位が全反応の律速段階であ ることが結論されている。

したがってい位に水素原子がなければこの反応は起き ない。この反応に使用する脂肪酸は通常飽和脂肪酸が用 いられ，不飽和脂肪酸を使用すると複雑なスルホン化物 を生成し着色する ${ }^{47)}$ 。二重結合に対する反応は丁度オレ フィンに対する無水硫酸の攻撃と同様である。

๙ースルホ脂肪酸は一部 Syndet bar に使用されている といわれているが詳かでない。特長もあり今後あるいは 新しい用途が開けるかも知れない。

\section{6 パラフィンのスルホン化反応}

特有の官能基を持たない長鎖のパラフィンに直接親水 基を導大する試みはかなり古くからなされている。界面 活性剤原料として合成化学的には最短コースの原料であ るがそのスルホン化は通常の試薬では不可でラジカル反 応が用いられる。そのひとつは 1936 年 Reed に よって開発されたスルホクロリネーション法であ $る^{48)}$ 。

$$
\begin{aligned}
& \mathrm{Cl}_{2} \longrightarrow 2 \mathrm{Cl} \cdot \\
& \mathrm{Cl} \cdot+\mathrm{RH} \longrightarrow \mathrm{R} \cdot+\mathrm{HCl} \\
& \mathrm{R} \cdot+\mathrm{SO}_{2} \longrightarrow \mathrm{RSO}_{2} \cdot \\
& \mathrm{RSO}_{2}+\mathrm{Cl}_{2} \longrightarrow \mathrm{RSO}_{2} \mathrm{Cl}+\mathrm{Cl} \cdot
\end{aligned}
$$

反応の開始に紫外線や放射線が必要で得られた スルホクロリドは加水分解してスルホン酸とな る。

もらひとつの方法はスルホキシデーション法 で，同様反応の開始に紫外線や放射線が必要で中 間的に生成するスルホ過酸は水で還元されてスル ホン酸となる。

$$
\begin{aligned}
& \mathrm{RH} \longrightarrow \mathrm{R} \cdot+\mathrm{H} \cdot \\
& \mathrm{R} \cdot+\mathrm{SO}_{2} \longrightarrow \mathrm{RSO}_{2} \cdot \\
& \mathrm{RSO}_{2} \cdot+\mathrm{O}_{2} \longrightarrow \mathrm{RSO}_{2} \mathrm{O}_{2} \cdot \\
& \mathrm{RSO}_{2} \mathrm{O}_{2} \cdot+\mathrm{RH} \longrightarrow \mathrm{RSO}_{2} \mathrm{O}_{2} \mathrm{H}+\mathrm{R} \cdot \\
& \mathrm{RSO}_{2} \mathrm{O}_{2} \mathrm{H} \longrightarrow \mathrm{RSO}_{3} \cdot+\mathrm{OH} \cdot \\
& \mathrm{RSO}_{3} \cdot+\mathrm{RH} \longrightarrow \mathrm{RSO}_{3} \mathrm{H}+\mathrm{R} \cdot \\
& \mathrm{OH} \cdot+\mathrm{RH} \longrightarrow \mathrm{H}_{2} \mathrm{O}+\mathrm{R} \cdot \\
& \mathrm{RSO} \mathrm{O}_{2} \mathrm{H}+\mathrm{H}_{2} \mathrm{O}+\mathrm{SO}_{2} \longrightarrow \mathrm{RSO}_{3} \mathrm{H}+\mathrm{H}_{2} \mathrm{SO}_{4}
\end{aligned}
$$

スルホ過酸は不安定な化合物で，できるだけ早く還元 してスルホン酸として取り除かないと着色や副反応物生 成の原因となる ${ }^{49)}$ 。

直鎖パラフィンを原料とした場合このようなラジカル， 反応ではスルホン化の位置は第一級炭素対第二級炭素に おのおのついた水素原子当たりの相対比で 1: 3.25 の割 合であり実際生成物は第二級のスルホネートを主体とし たものである。スルホクロリネーション，スルホキシデ ーションに関しては Asinger 教授の著書に詳しい50)。

この反応は開始手段として紫外線, 放射線いずれの使 用が有利かが論議の対象となっている。反応は先に示し. たように連鎖機構で説明され，ラジカル生成の連鎖を停: 止させないことがエネルギーの有効利用につながる。

Esso 社はスルホキシデーションを放射線 $\left({ }^{60} \mathrm{Co} に よ:\right.$ る $r$ 線) で開始寸る方法を研究し中間試験装置を建設し た。

最近日本でもこのプロセスの実施計画がある会社があ， $る^{5)}$ 。

このプロセスフローシートは図-3 に示した。

${ }^{60} \mathrm{Co}$ による照射後, 後反応器を用いて反応を持続さ せている。この連鎖反応を長く保たせるためにはパラフ ィン中の不純分とくに芳香族炭化水素を $5 \mathrm{ppm}$ 以下に . また水を存在させないことが必要である。

一方 Hoechst 社は同じスルホキシデーションを紫外 線照射の方法で工業化した。このプロセスは LightWater 法と呼ばれ反応中に水を共存させて生成するス ルホ過酸をただちにスルホン酸として安定化し，さらに

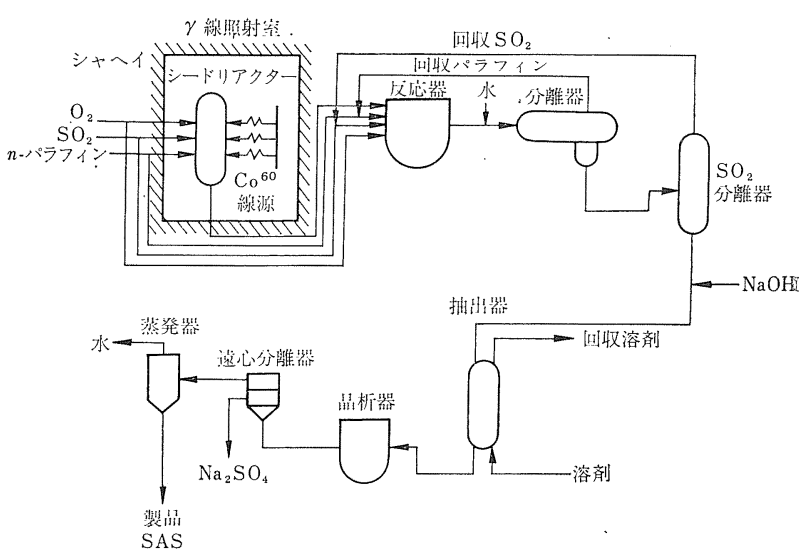

図-3 $\gamma$ 線照射によるパラフィンスルホネート (SAS) 製造工程図 


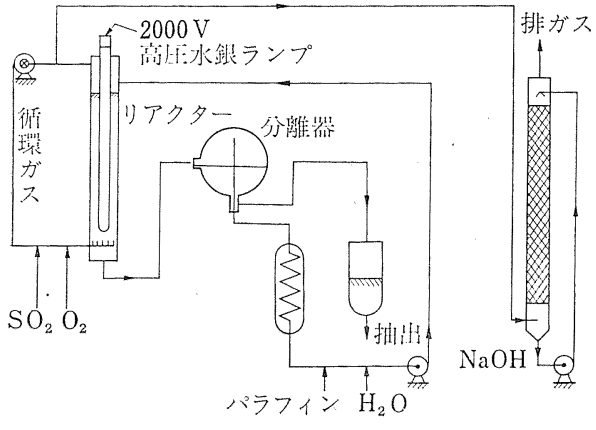

図-4 Hoechst 社における Light-Water 法 パイロットプラント

衣-5 種々の線量率に おける $\mathrm{G}$ 值

\begin{tabular}{l|c}
\hline $\begin{array}{c}\text { 線 量 率 } \\
(\mathrm{rad} / \mathrm{hr})\end{array}$ & $\begin{array}{c}\mathrm{G} \text { 值 } \\
(\text { スルホン酸 })\end{array}$ \\
\hline $1.0 \times 10^{4}$ & 0 \\
$6.0 \times 10^{4}$ & $190 \pm 40$ \\
$2.5 \times 10^{5}$ & $270 \pm 40$ \\
$3.0 \times 10^{5}$ & $250 \pm 30$ \\
\hline
\end{tabular}

水抽出によりスルホン酸を回 収しパラフィンをリサイクル して使用する方式を採用し比 較的品質の良いスルホネート を得ている(図-4 ${ }^{52)}$ 。 低反応率のらちにスルホン 酸を回収することは，ジスル ホン化反応の防止となるが，

水の存在はラジカル生成の連鎖を停止する。

Rösinger は放射線を用いて同じ水添加プロセスへの 適用を研究し報告した ${ }^{53)}$ 。この場合の $\mathrm{G}$ 值は 表-5 に示 す。

Light-Water 法の運転成果 ${ }^{54)}$ よその量子収率は 10 〜15 であり $\mathrm{G}$ 值として比較推算 ${ }^{55}$ してみると 400 程度 となり同社が柴外線法を有利と判断した根拠がうかがえ る。Rösingerによれば放射線の使用はかなり大型の $5 \times$ $10^{6} \mathrm{Ci}$ 線源を使わないかぎり光反応の方が有利であると している。Light-Water 法の場合でもパラフィンの純度 恃高いことが必要で芳香族化合物は反応を阻害する。

一方 Asinger 教授は Light-Water 法の欠点として水 相に亜硫酸が溶けやすいため，よほど反応率を下げてス ルホン酸回収とパラフィン循環を行なわないと, 水相に 溶けたスルホン酸がさらにスルホン化されてジスルホン

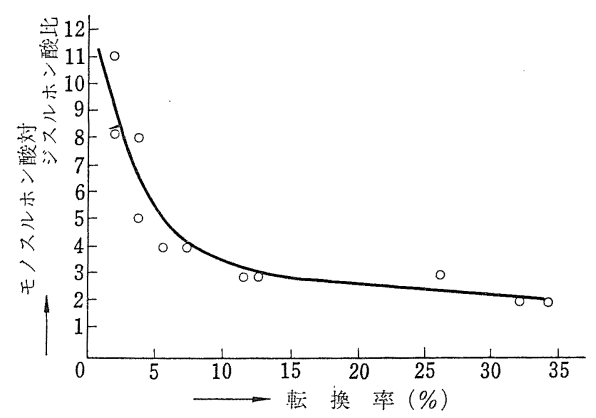

図-5 $\quad \mathrm{C}_{13} \sim \mathrm{C}_{17}$ パラフィンのスルホキシデーションに おける転換率とアルキルモノスルホン酸/ジス ルホン酸比の関係
酸を生成しやすいと指摘している。この改良には無水酢 酸を使用することによりスルホ過酸の害をなくし，かつ 反応率向上に役立つと主張した。またクロル系の溶媒 (四塩化炭素，クロロホルムなど）の併用も同様の効果 がある ${ }^{56)}$ 。

転換率とモノ，ジスルホン酸の生成比率を図-5に示 した。転換率を上げようとすると急速にジスルホン化が おきて好ましくない結果となる。

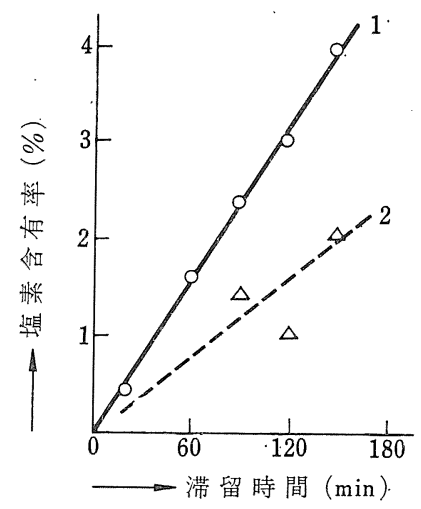

1. $-\mathrm{SO}_{2} \mathrm{Cl}$ としての $\mathrm{Cl}$ 含有率

2. $\mathrm{C}-\mathrm{Cl}$ としての $\mathrm{Cl}$ 含有率

図-6 PC-2,5 装置に打ける スルホクロル化と直接 クロル化の関係
ソビエトにおいて はスルホクロリネー ションを放射線の利 用で実施してG值が $10^{6}$ と非常に有利で あることを Osipov が報告している ${ }^{57) 。 ~}$ スルホクロリネーシ ョンでは先に示した ように水の副生によ る連鎖の停止がなく 有利であるが，同時 にクロル化反応も副 生するので反応は $30 \%$ 転換に止めて運 転する(図-6 参照)。

実際の装置は直径
$0.8 \mathrm{~m}$, 深さ $4 \mathrm{~m}$, 容量 $2 \mathrm{~m}^{3}$ で $1,530 \mathrm{Ci}$ の ${ }^{60} \mathrm{Co}$ を用い $700 \mathrm{~kg} / \mathrm{hr}$ 生産し, その建設費は 80,000 ルーブルである。

しかしクロル化の副反応によるクロルパラフィンの副 生や，高転換率ではジスルホクロル化反応もかなり多く なり品質にはかなり問題があらう。

パラフィンのスルホン化反応はすでにかなり長い歴史 があるが，今日なお工業的に確立していない感がある。

\section{7 亜硫酸による不飽和化合物のスルホン化}

オレフィンの二重結合に対する亜硫酸塩の付加は古く から研究されているがなお充分解明されていない。

$\mathrm{R}-\mathrm{CH}=\mathrm{CH}_{2}+\mathrm{NaHSO}_{3} \stackrel{\text { ラシカル開始 }}{\longrightarrow} \mathrm{R}-\mathrm{CH}_{2} \mathrm{CH}_{2} \mathrm{SO}_{3} \mathrm{Na}$

この反応は Kahrasch らによって研究され，(1) 反応 開始に酸化剂が必要，(2) $\propto$-オレフィンに対して反マル コウニコフ付加により 1-アルカンスルホン酸塩を生成, （3）ラジカル阻害剤に感じやすい，ことを認め，Mayo ら ${ }^{58}$ はつぎのようなラジカル・イオン機構をもって説明 している。

開始: $\mathrm{SO}_{3}{ }^{2-}+$ 酸化剂 $\rightarrow \cdot \mathrm{SO}_{3}{ }^{-}+$酸化剂 ${ }^{-}$

付加 : $\cdot \mathrm{SO}_{3}{ }^{-}+\mathrm{RCH}=\mathrm{CH}_{2} \rightarrow \mathrm{R}-\mathrm{CHCH}_{2} \mathrm{SO}_{3}^{-}$

連鎖: $\mathrm{R}-\mathrm{CHCH}_{2} \mathrm{SO}_{3}{ }^{-}+\mathrm{HSO}_{3}{ }^{-}$

$$
\rightarrow \mathrm{RCH}_{2} \mathrm{CH}_{2} \mathrm{SO}_{3}^{-}+\cdot \mathrm{SO}_{3}^{-}
$$

二重結合に共役系のカルボニル基，シアノ基，ニトロ 
基などを有する化合物にはイオン的に付加する。たとえ ばマレイン酸エステルのスルホン化によるスルホコ八ク 酸塩古くより界面活性剤とし使用されている。

$\mathrm{RCH}: \mathrm{CHC}: \mathrm{O} \rightleftharpoons \mathrm{R} \stackrel{\oplus}{\mathrm{CH}} \stackrel{\ominus}{\mathrm{CHC}}: \mathrm{O} \rightleftharpoons \mathrm{RCHCH}: \mathrm{C}^{-} \mathrm{O}^{-}$ \begin{tabular}{l|l|c}
$\mathrm{OR}$ & $\mathrm{O}$ & $\mathrm{O}$ \\
$\mathrm{SO}_{3}{ }^{2-} ; \mathrm{H}^{+}$ & $\mathrm{SO}_{3}{ }^{2-} ; \mathrm{H}^{+}$
\end{tabular} $\mathrm{RCHCH}_{2} \mathrm{C}: \mathrm{O} \quad \mathrm{RCHCH}: \mathrm{COH}$ $\mathrm{SO}_{3}^{-} \mathrm{OR} \quad \mathrm{SO}_{3}^{-} \quad \mathrm{OR}$

๔ーオレフィンに対する重刺硫酸塩のラジカル付加に よるアルカンスルホン酸塩の合成研究は最近も二, 三の 報告があり工業化への努力が続けられている。

๔-オレフィンと 重亜硫酸塩の共通溶媒 として第三ブ タノールを用い紫外線照射の下に $\mathrm{pH}$ 5 9 亿調節しつ つ反応する。

この際光増感剂としてケトン, 芳香族化合物が有効で とくに第三ブタノールの $20 \%$ 2-ブタノンに置換し た場合 $95.6 \%$ の転換率を得ている ${ }^{599}$ 。

オレフィンを暴気して過酸化物を一部生成させてから 重亜硫酸塩を反応させアルカンスルホン酸塩を合成する 方法む方る ${ }^{60)}$ 。同じ研究者によって硝酸塩の添加の下に 酸素を吹き込むと $92 \%$ 以上の反応率で $\mathrm{C}_{15 \sim 18}$ の め-オ レフィンをスルホン化できることが報告されている この反応機構はつぎのように考光られている

$$
\begin{aligned}
& \text { 開始 }:\left[\begin{array}{l}
: \ddot{O}: \\
: \ddot{O}: \ddot{N} \\
: \ddot{O}:
\end{array}\right]^{-}+\left[\begin{array}{l}
: \ddot{O}: \\
: \ddot{S}: \ddot{O}: \\
: \ddot{O}:
\end{array}\right]^{-}
\end{aligned}
$$

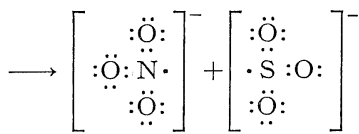

$$
\begin{aligned}
& \cdot \mathrm{NO}_{2}+\mathrm{SO}_{3}{ }^{2-} \rightarrow \mathrm{NO}_{2}{ }^{-}+\cdot \mathrm{SO}_{8}{ }^{-} \\
& \mathrm{O}_{2}+\mathrm{SO}_{3}{ }^{2-} \rightarrow\left[\cdot \mathrm{O}_{2}{ }^{-}\right]+\cdot \mathrm{SO}_{3}{ }^{-} \\
& \mathrm{RCHCH}_{2} \mathrm{SO}_{3}{ }^{-}+\mathrm{HSO}_{3}^{-} \\
& \rightarrow \mathrm{RCH}_{2} \mathrm{CH}_{2} \mathrm{SO}_{3}^{-}+\cdot \mathrm{SO}_{3}^{-} \\
& \mathrm{RCHCH}_{2} \mathrm{SO}_{3}{ }^{-}+\cdot \mathrm{SO}_{3}{ }^{-} \rightarrow \mathrm{RCHCH}_{2} \mathrm{SO}_{3}{ }^{-} \\
& \mathrm{SO}_{3}^{-} \\
& \underset{\mathrm{RCHCH}}{2} \mathrm{SO}_{3}^{-}+\cdot \mathrm{X} \rightarrow \underset{\mathrm{X}}{\mathrm{RCHCH}_{2} \mathrm{SO}_{3}^{-}}
\end{aligned}
$$

硝酸塩の存在はラジカル・イオンの生成に役立ち反応 を開始する。実際オレフィン $1 \mathrm{~mol}$ に硝酸カリウム 0.2 mol の添加が適している。๙ーオレフィンの重亜硫酸塩付 加反応は現在の所大規模に工業化された例は見当たらな い。1-アルカンスルホン酸塩が比較的難溶性であるなど 性能上の問題にも関連があって 3 項で述べた無水硫酸に よる反応が今後とも広く使用されると思う。

\section{8 最近のスルホン化装置}

洗剤工業の進展とともにスルホン化装置も大型化さ
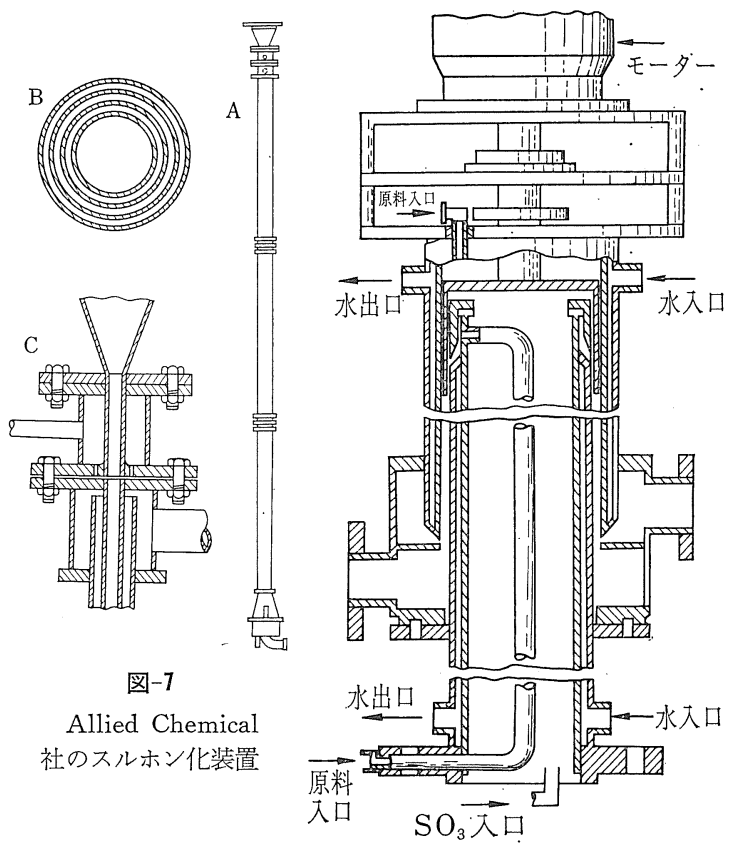

図-8 Chemithon 社のスルホン化装置

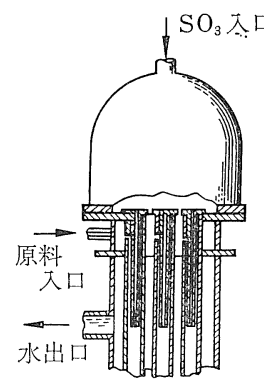

れ,連続化している。とくに無 水硫酸を使用する連続プロセ スが急速に普及している。一 般的な概況については須々木 らの総説㤩を参照されたい。

無水硫酸法による連続スル ホン化洗剤製造装置を初めて 大型化したのはイタリアの Ballestra 社の Sulfurex Process で Silvis により紹介さ れている ${ }^{63)}$ 。

この方法は回分型の反応力 ンが直列になっている。薄膜 接触式のスルホン化プロセス は初め du Pont 社により考

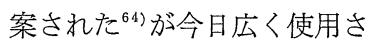
れているのは Allied Chemical 社 $^{65)}$ と Chemithon 社 $^{66}$ のものであろら。これらの詳 細は多くのノウハウの部分を 含んでいると思われるが， Allied Chemical 社の反応器 を図-7 に Chemithon 社のものを図-8 に示した。いず れも円筒の内面で薄膜流となり希釈された無水硫酸ガス と接触しスルホン化する。図-7 で A はその全体を示し Bはその切断面で内外部より冷却するようになっており Cはその頂部の構造を示す。 
図-8の Chemithon 社の装置は頂部に回転部分があ って内外の二重円筒に薄膜流を形成させる点に特長があ り器内はいくら加加圧されている。

これらの装置で問題になるのは反応熱の除去方法で, Proctor \& Gamble 社の特許 ${ }^{67)}$ ではシェルアンドチュ 一ブ型にして熱交换を改善しているが実装置として実存 するかは明らかでない（図-9)。

以上最近とくに注目されている無水硫酸法による装置 にいつて述たが，この反応は非常に速い。発熱量の大き い，適温範囲が小さいかつ滞溜時間の制御に㛜密を要す る反応であるので接触効果の良い機構が要求される。

また被スルホン化物の物性により条件が異なるがこれ らについては多くのノウハウの部分を含んでいるのでこ こでは詳細述べられない。

無水硫酸以外を使用するスルホン化装置については最 近とくに新しい進歩は見当たらない。

\section{9 結言}

以上述べてきたスルホン化反応は古くから実用化され ながら，なおその激しい反応のため多くの基礎的な解明 が必要とされているほか, 界面活性剤の親油基源が合成 化学とくに石油化学の進展とともに新しい材料が提供さ れており，それに適合する試薬，反応方式がつぎつぎと 改善されてきている。

しかもコルベン・ワークで見いだされた反応とその生 成物が反応カンによって容易にスケールアップしえた時 代は過ぎ去り，原料に適した反応方式を実験の段階から 充分考慮して研究を進めなければ誤った判断を下すこと にならら。著者らはンフィンスルホン酸塩の開発に当 たって, その当初から化学や化学工学や装置の専門家を もってプロジェクトチームを組むことにより成功しえた 経験はこの点を如実に示していると考える。

今後のこの分野での開発は原料合成の研究者, 界面活 性剂研究者, さらには物理化学, 化学工学, 電気, 機械 の多くの分野の専門家が研究の当初から密接に協力して いくことが新たな進歩発展を可能にする道であると考え る。

\section{(昭和 45 年 7 月 3 月受理)$$
\text { 文献 }
$$

1) 富山, 油化学, 17, 642 (1968)

2) 田尻, 日化協日報, 312 (1970)

3) E.E. Gilbert "Sulfonation and Related Reactions" (1965) Interscience Publishers

4) H. Cerfontain "Mechanistic Aspects in Aromatic Sulfonation and Desulfonation" (1968) Interscience Publishers

5）赤林, 石油誌, 9, 145 (1966)

6) 須々木, 阿部, 大越, 油化学, 16, 311 (1967)

7) F.J. Kremers, A. Shultz, CSMA Meeting, Dec., (1969)

8) C.W.F. Kort, H. Cerfontain, Rec. Trav. Chim.,
87, 24 (1968); 86, 865 (1967)

9) J.K. Bosscher, H. Cerfontain, Rec. Trav. Chim., 87, 873 (1968)

10) H. Shoji, K. Majima, J. Am. Oil Chemists' Soc., 40, 179 (1963)

11) E.E. Gilbert, B. Veldhuis, Ind. Eng. Chem., 47, 2300 (1955)

12) F.W. Gray, J. Krems,J. Org. Chem., 26, 209 (1961)

13) A.C.M. Wanders, H. Cerfontain, Rec. Chem., PaysBas, 86, 1199 (1967)

14）木村, 谷森, 下, 油化学, 15, 264 (1966)

15) 木村, 谷森, 下, 油化学, 14, 63 (1965)

16) 木村, 谷森, 下, 油化学, 15, 315 (1966)

17) R. Brooks, B. Brooks, U.S. 3,069,243 (1962)

18) R.R. Warren, Am. Oil Chemists Soc., 56 th Meeting April 25 28 (1965)

19) W.K. Seifert, Tenside, 2, 150, 182, 216 (1965)

20) 富山, 油化学, 19, 359 (1970)

21) J.R. Livingston, Jr., R. Drogin, R.J. Kelly, Ind. Eng. Chem. (Products \& Research Development), 4, 28 (1965)

22) W.E. Truce, D.N. Bundge, R.J. Steltenkamp, J. Org. Chem., 27, 3913 (1962)

23) O. Lasarenko, Ber., 7, 125 (1874)

24) F.B. Downing, C. Point, R.G. Clarkson, U.S. 2,061,617 , 620 (1936); 特許権者 E.I. du Pont de Nemours \& Co.

25) F. Püschel, Tenside, 4, 320 (1967)

26) F.G. Bodwell, M.L. Peterson, C.F. Rondestvedt, $J$. Am. Chem. Soc., 76, 3945 (1954)

27) D.M. Marquis, S.H. Sherman, R. House, W.A. Sweeney, J. Am. Oil Chemists' Soc., 43, 607(1966)

28) M. Nagayama, H. Okada, Belg., 731,492 (1969) 特 許権者 Lion Fat \& Oil Co.

29）永山, 岡田, 森, 富山, 工化, 72, 2248 (1969)

30）森, 永山, 谷口, 青木, 未発表

31) D.M. Marquis, Hydrocarbon Processing, 47, 109 (1968)

32）宮内, 須々木, 化学工学協会第 3 回秋季大会 (1969)

33）永山, 岡田, 万代, 青木, 日本化学会第 22 年会 (1969)

34) 永山, 万代, 阪谷, 森, 日本化学会第 23 年会 (1970)

35）森, 永山, 万代, 未発表

36) D.N. DeMott, U.S. 3,471,535 特許権者 Procter \& Gamble Co.

37) G.F. Kite, U.S. 3,502,716 (1970) 特許権者 Gulf Research \& Development Co.,

38）八ロルド・ロイド・ジモンド，特許出願公告 昭-45-16932， 出願人 ガルフ・リサーチ・エンド・デベロップメント・ コンパニー

39) W. Stein, E. Unterbach, H. Baumann, M. Voss, U.S. $3,424,693 ;$ U.S. 3, 424,694 (1964)

40) Unilever N.V., Belg., 737, 560 (1970)

41）トピックス, 化学工業, 21, 431 (1970)

42) C.Q. Sheely, Jr., R.G. Rose, Ind. Eng. Chem. (Products \& Research Development), 4, 24 (1965)

43) R.C. Myerly, Sulfation of Tergitol Nonionic 15-S-3 (U.C.C. 社資料)

44) A.J. Stirton et al., J. Am. Oil Chemists' Soc., 31, 13 (1954); 32, 370 (1955); 33, 44 (1956); 34, 100 (1957); 37, 295, 674 (1960); 38, 493 (1961); 39, 55, 128, 168 (1962); 42, 233 (1965)

45) 浅原ら, 油化学, 9, 468 (1960)；14, 237, 500 (1965) 
46) E.A. Jeffery, D.P.N. Satchell, J. Chem. Soc., 1962, 1913

47) T.W. Sauls, W.H.C. Ruggeberg, J. Am. Oil Chemists' Soc., 33, 383 (1956)

48) C.F. Reed, U.S. 2,046,090 (1936)

49) D.O. Hummel, W. Mentzel, C. Schneider, Ann., 639, 13 (1964)

50) F. Asinge, Paraffins Chemistry and Technology", (1967) Preganon Press

51）波多野，日化協月報，306（1970）

52) C. Beermann, Europian Chemical Nerws, Dec., 2, 39 (1966)

53) S. Rösinger, Symposium on the utilization of large radiation source \& accelrators in industrial processing Munich 18-22 August (1969)

54) Farbwerke Hoechst A.G., Neth. Patent Application 65-14137 (1965)

55）雨宮 “放射線化学入門”（昭和 37 年発行）丸善

56) F. Asinger, Symposium on the utilization of large radiation source \& accelerators in industrial processing munich 18-22 August (1969)

57) V.B. Osipov, Presentation at the 8 th conference on radioisotopes, Japan, Nov. 13-16 (1967)

58) F.R. Mayo, C. Walling, Chem. Rev., 27, 394 (1940)

59) C.L. Furrow, C.E. Stoops, Ind. Eng. Chem. (Products Research \& Development), 7, 26 (1968)

60) C.J. Norton, F.L. Dormish, M.J. Reuter, N.F. Seppi, P.M. Beazley, American Chemical Society, Houston Meeting, Feb. 22-27 (1970) 特許出願公告 昭 43-11207 出願人マラソン・オイル・カンパニー

61) C.J. Norton, D.E. Drayer, Hydrocarbon Processing, 49, 140 (1970)

62) C.J. Norton, N.F. Seppi, M.J. Reuter, J. Org. Chem., 33, 4158 (1968)

63) S.J. Silvis, M. Ballestra, J. Am. Oil Chemists' Soc., 40, 618 (1963)

64) K. Talk, W.R. Taplin, U.S. 2,923,728 (1960) 特許 権者 E.I. du Pont de Nemours \& Co.

65）ジョン・エドウィン・ヴァンダー・メイ，特許出願公告 昭 43-18885 出願人 アライド・ケミカル・コーポレーシ ヨン

66) リチャード・ジェイ・ブルックス，バートン・ブルック ス, 特許出願公告 昭 $42-252$

67) Procter \& Gamble Co., Canada 80,012 (1968) 